\title{
MODERASI KEYAKINAN HUKUM KARMA DAN MORALITAS PADA HUBUNGAN WHISTLEBLOWING DAN PENCEGAHAN KECURANGAN
}

\author{
Ni Wayan Yuniasih ${ }^{1}$ I Wayan Sudiana ${ }^{2}$ I Putu Deddy Samtika Putra ${ }^{3}$
}

Article history:

Submitted:

29 Oktober 2021

Revised:

24 November 2021

Accepted:

29 November 2021

\section{Keywords:}

Whistleblowing;

Belief in Law of Karma Phala;

Morality;

Fraud Prevention;.

\section{Kata Kunci:}

Whistleblowing;

Keyakinan Hukum Karma

Phala;

Moralitas;

Pencegahan Kecurangan

\section{Koresponding:}

Universitas Hindu Indonesia,

Bali, Indonesia

Email:

yuniasihwayan@unhi.ac.id

\section{Abstract}

Various research results indicate that the implementation of whistleblowing in fraud prevention is influenced by other factors. This study purpose to test the effectiveness of the whistleblowing and examine the spiritual and moral factors that may affect its effectiveness. This research was conducted at 34 People's Credit Institutions in Denpasar City. Research respondents totaled 84 people who were determined by probability sampling technique. The research variables were measured by the indicators contained in the statement of the questionnaire. Data analysis was performed using moderated regression analysis. The results showed that whistleblowing had a positive effect on fraud prevention. The belief in the law of karma phala is able to moderate the whistleblowing relationship and prevent fraud. Individuals who believe in the law of karma phala will use the whistleblowing system to assist organizations in preventing fraud. Individual morality is also able to moderate the whistleblowing relationship and fraud prevention.

\begin{tabular}{l} 
Abstrak \\
\hline \\
Hasil penelitian yang beragam mengindikasikan bahwa dalam penerapan \\
whistleblowing dalam pencegahan kecurangan dipengaruhi faktor lain. \\
Penelitian ini bertujuan untuk menguji efektivitas whistleblowing system dan \\
menguji faktor spritual serta moralitas yang mungkin mempengaruhi \\
efektivitas tersebut. Penelitian ini dilakukan pada 34 Lembaga Perkreditan \\
Rakyat yang ada di Kota Denpasar. Responden penelitian berjumlah 84 \\
orang yang ditentukan dengan teknik probability sampling. Variabel \\
penelitian diukur dengan indikator yang tertuang dalam penyataan kuesioner. \\
Analisis data dilakukan dengan menggunakan moderated regression \\
analysis. Hasil penelitian menunjukkan wisthleblowing berpengaruh positif \\
pada pencegahan kecurangan. Keyakinan hukum karma phala mampu \\
memoderasi hubungan wisthleblowing dan pencegahan kecurangan. Individu \\
yang memiliki keyakinan hukum karma phala akan memanfaatkan sistem \\
wisthleblowing untuk membantu organisasi dalam mencegah terjadinya \\
kecurangan. Moralitas individu mampu memoderasi hubungan \\
wisthleblowing dan pencegahan kecurangan.
\end{tabular}

Universitas Hindu Indonesia, Bali, Indonesia ${ }^{2}$

Email:sudianawayan@ymail.com

Universitas Hindu Indonesia, Bali, Indonesia ${ }^{3}$

Email: deddy.samtika@gmail.com 


\section{PENDAHULUAN}

Indonesia menempati peringkat 89 dalam tingkat korupsi berdasarkan nilai Corruption Perfection Index (CPI) untuk tahun 2018 dari 180 negara sedangkan di kawasan Asia Tenggara berada pada posisi keempat (Transparency International, 2020). Berdasarkan data Indonesia Corruption Watch (ICW) tahun 2019 jumlah kasus korupsi di Indonesia mencapai 580 kasus dibandingkan tahun 2018 sejumlah 454 kasus. Salah satu lembaga yang rentan terhadap kecurangan yaitu lembaga di bidang keuangan. Lembaga Perkreditan Desa (LPD) adalah salah satu bentuk lembaga keuangan non perbankan yang hanya ada di Bali. Dalam operasionalnya LPD memerlukan tata kelola yang baik agar perkembangan lembaga ini semakin maksimal (Parmawan et al., 2017). Namun, seiring perkembanganya LPD tidak luput dari kasus kecurangan. Berdasarkan laporan yang masuk di Kejaksaan Negeri Denpasar, diduga telah terjadi penyalahgunaan dana nasabah di LPD Desa Serangan sehingga terjadi penyegelan oleh masyarakat sejak Oktober 2020 seperti yang dimuat dalam Radar Bali.

Tindakan pencegahan diperlukan untuk mengurangi terjadinya kasus kecurangan. Pencegahan kecurangan adalah bentuk tindakan yang diterapkan dalam rangka mencegah individu melakukan tindakan curang yang sifatnya menimbulkan kerugian (Hariawan et al., 2020). Salah satu mekanisme yang dapat diterapkan yaitu whistleblowing system (Hakim et al., 2017). Menurut (Komite Nasional Kebijakan Governance (KNKG), 2011), efektivitas penerapan mekanisme whistleblowing akan meningkatkan peran serta masyarakat dan internal perusahaan untuk mengambil tindakan guna mencegah terjadinya kecurangan dengan membuat laporan ke pihak yang berwenang menangani masalah tersebut. Pada awal abad ke-21 efektivitas penerapan whistleblowing dalam rangka mengungkapkan kecurangan atau kasus keuangan telah banyak dibuktikan (Dyck et al., 2010). Para akuntan dan regulator di Amerika Serikat dan negara lain telah memberikan pengakuan pada efektifitas whistleblowing dalam mengungkapkan kecurangan laporan keuangan (Patel, 2003); (Miceli et al., 2013). Peran serta dan kepedulian masyarakat untuk menjadi whistleblower akan sangat efektif dalam pengungkapan terjadinya kasus korupsi dan kecurangan (Rustiarini \& Sunarsih, 2017).

Penelitian tentang efektifitas penerapan whistleblowing dalam pencegahan fraud sudah dilakukan, namun hasil yang ditemukan masih beragam. (Wijaya et al., 2017) menemukan bahwa whistleblowing berpengaruh negatif pada kecurangan akuntansi di LPD Kecamatan Gerokgak. Penelitian (Purnamawati, 2018) menemukan whistleblowing berpengaruh positif pada pendeteksian fraud. Hasil penelitian Sujana et al., (2020); Cahyo \& Sulhani, (2017) yang menemukan bahwa whistleblowing system tidak berpengaruh terhadap pencegahan kecurangan dalam pengelolaan keuangan desa. Romadaniati et al., (2020); Pamungkas et al., (2017) menemukan bahwa whistleblowing memiliki pengaruh positif pada pencegahan kecurangan. Jayanti \& Suardana, (2019) juga menemukan bahwa 
whistleblowing berpengaruh positif pada pencegahan kecurangan.

Hasil penelitian yang beragam mengindikasikan bahwa dalam penerapan whistleblowing dalam pencegahan kecurangan dipengaruhi faktor lain. Pendekatan teori kontinjensi digunakan untuk menjelaskan peran faktor kondisional sebagai variabel moderasi hubungan antara variabel independen dan variabel dependen (Brownell, 1983). Faktor kondisional berasal dari internal maupun eksternal organisasi yang dikelompokkan menjadi empat yaitu kultur, organisasional, interpersonal, dan individual. Penerapan whistleblowing tidak terlepas dari karakteristik individu dalam organisasi. Keyakinan pada karma phala dipilih sebagai variabel moderasi dalam penelitian ini karena cara seseorang menilai etis atau tidaknya suatu tindakan bergantung pada keyakinannya (Hafizhah, 2016). Tidak semua orang bisa menjadi whistleblower, hanya individu dalam organisasi yang akan efektif untuk menjadi whistleblower (Gaurina et al., 2017).

Perilaku individu timbul karena adanya niat untuk berperilaku sesuai dengan Theory of Planned Behavior (TPB). Sementara teori perilaku prososial dapat digunakan untuk menjelaskan pembuatan keputusan etis individual terkait dengan niat melakukan whistleblowing (Rustiarini \& Sunarsih, 2017). Salah satu nilai kearifan lokal yang dinilai mampu mempengaruhi sikap dan perilaku individu dalam untuk melakukan whistleblowing yaitu keyakinan pada karma phala. LPD sebagai sebuah lembaga keuangan yang berada di lingkungan desa adat sangat memegang teguh konsepkonsep keagamaan salah satunya terkait hukum karma phala. Ajaran karma phala sudah diajarkan saat seseorang berada di lingkungan keluarga saat menuntut ilmu (brahmacari) hingga saat hidup bermasyarakat. Hukum karma berpandangan bahwa segala hal yang dilakukan, katakan, atau pikirkan akan menghasilkan dampak dan suatu ketika akan kembali pada kita (Chakraborty \& Chakraborty, 2006). Apabila perbuatan didasari oleh niat/keinginan bathin adharma maka cepat atau lambat akibat dari perbuatan tersebut akan diterima meskipun tidak diinginkan (Purnamawati et al., 2019).

Konsep karma selalu diterapkan sebagai filosofi tindakan praktis. Menurut filosofi ini, karma bukan hanya hukum spiritual, tetapi juga prinsip yang menuntut niat baik. Individu yang percaya pada hukum karma akan bertindak mengelola pikiran dan emosi dengan baik untuk dapat mengambil keputusan yang etis (Ziegenfuss \& Singhapakdi, 1994; Fraedrich \& Ferrell, 1992; Aksiana \& Sujana, 2019). Individu akan berusaha menjaga moral dan etikanya di masyarakat ketika individu tersebut memiliki keyakinan yang tinggi pada hukum karma (Munidewi, 2017).

Selain keyakinan pada hukum karma phala, perilaku individu tidak terlepas dari moralitas yang dimiliki. Menurut Rahimah et al., (2018), pencegahan kecurangan akan lebih efektif ketika individu mempunyai moralitas yang tinggi karena mereka memiliki kecenderungan untuk mematuhi peraturan yang ada sesuai dengan prinsip-prinsip etika yang berlaku umum, sebaliknya individu dengan moralitas rendah cenderung mengambil keputusan sesuai dengan hal-hal yang diinginkan saja. Seseorang akan 
bersedia menjadi whistleblower dipengaruhi oleh budaya dan nilai-nilai etika yang dijadikan pedoman organisasi. Tingkat penalaran moral yang dimiliki individu akan mempengaruhi kecenderungan individu tersebut untuk melakukan whistleblowing (Manafe, 2015).

Ketika individu memiliki penalaran moral yang tinggi maka cenderung akan melakukan whistleblowing jika dibandingkan dengan individu yang memiliki tingkat penalaran moral yang lebih rendah. Romadaniati et al., (2020) menemukan bahwa moralitas seseorang berpengaruh pada hubungan whistleblowing dan pencegahan kecurangan. Sesuai dengan uraian latar belakang tersebut maka penelitian ini ingin menguji pengaruh penerapan whistleblowing system pada pencegahan kecurangan di LPD Kota Denpasar dan menguji variabel moderasi keyakinan hukum karma pala dan moralitas. Sebagai kota yang berawawasan budaya ditengah perkembangan perekonomian membuat LPD di Denpasar menarik untuk dijadikan lokasi penelitian.

\section{METODE PENELITIAN}

Penelitian ini menggunakan semua karyawan yang bekerja Lembaga Perkreditan Desa di Denpasar sebagai populasi dengan jumlah seluruh LPD yaitu 34 kantor LPD dengan jumlah karyawan sebanyak 537 orang.

Sampel penelitian ditentukan dengan menggunakan metode non probability sampling yaitu sampling insidental. Responden yang diberikan kuesioner adalah karyawan yang kebetulan ditemui saat penyebaran kuesioner dilakukan dan dipandang layak untuk dijadikan responden. Jumlah responden penelitian ditentukan berdasarkan rumus Slovin (Sugiyono, 2017):

$$
n=\frac{\mathrm{N}}{1+\mathrm{Ne}^{2}}
$$

Keterangan:

n: ukuran sampel

$\mathrm{N}$ : ukuran populasi

e: kelonggaran ketidak telitian atau derajat toleransi

Berikut perhitungan sampel dengan rumus Slovin:

$$
n=\frac{537}{1+537 \times 0,1^{2}}=84,3
$$

Sebanyak 34 LPD dijadikan unit sampel penelitian dengan total responden sebanyak 84 orang. Setiap LPD ditentukan jumlah responden sebanyak 2 sampai 3 orang. LPD.

Whistleblowing system didefinisikan sebagai sebuah sistem yang dirancang untuk melaporkan kecurangan dengan kriteria tertentu, tindak lanjut atas laporan tersebut, imbalan dan perlindungan kepada pelapor atau whistleblower, serta hukuman atau sanksi bagi pihak terlapor. Indikator yang digunakan untuk variabel ini yaitu: efektifitas penerapan whistleblowing system, cara pelaporan pelanggaran, dan manfaat whistleblowing system (Swardayantara, 2019).

Karma phala adalah hasil dari perbuatan seseorang. Dalam penerapan konsep karma pala diyakini bahwa segala perbuatan yang baik akan memberikan hasil yang baik dan perbuatan yang buruk memberikan hasil yang buruk. Indikator yang 
digunakan untuk mengukur keyakinan pada hukum karma phala adalah sejauh mana individu meyakini hasil dari perbuatan yang dilakukan (Vinayanthi et al., 2020).

Moralitas adalah tekad mengikuti apa yang ada dalam hati manusia dan disadari sebagai kewajiban mutlak. Adapun indikator moralitas yaitu kesadaran seorang karyawan akan tugasnya dalam organisasi, ketaatan pada peraturan organisasi yang berlaku, nilai kejujuran dan etika, serta sikap seseorang ketika melakukan perbuatan yang tidak jujur (Rahimah et al., 2018).

Pencegahan kecurangan adalah suatu tindakan yang dirancang untuk menurunkan kemungkinan terjadinya kecurangan dengan membatasi ruang gerak para pelaku. Adapun indikator pencegahan kecurangan yaitu menciptakan kejujuran, transparansi, saling bantu, proses rekrutmen yang transparan, fraud awareness, kode etik yang jelas, lingkungan kerja yang baik, mudah dimengerti dan ditaati, program bantuan kepada karyawan yang mengalami kesulitan, dan sanksi jika terjadi kecurangan. Pernyataan kuesioner untuk mengukur pencegahan kecurangan mengacu pada penelitian (Sujana et al., 2020).

Teknik analisis data yang digunakan dalam penelitian ini adalah moderated regression analysis yang terdiri dari beberapa tahapan. Pengujian validitas instrumen dilakukan dengan melihat nilai pearson correlation > 0,30. Pengukuran reabilitas instrumen penelitian dilakukan dengan menggunakan Cronbach alpha. Suatu konstruk atau variabel dikatakan reliabel apablia nilai cronbach alpha > dari 0,70 (Ghozali, 2016). Uji normalitas data dilakukan dengan uji statistik one sampel Kolmogrof-Smirnov (K-S) dengan probalititas signifikan di atas 0,05, maka persamaan regresi terdistribusi secara normal (Ghozali, 2016). Uji glejser dilakukan untuk mengetahui ada atau tidaknya msalah heteroskedastisitas dalam persamaan regresi. Pendeteksian ada atau tidaknya korelasi atara variabel bebas dapat dilakukan dengan melihat nilai tolerance inflation factor (VIF). Apabila nilai tolerance $>0,10$ dan nilai variance inflation factor (VIF) $<10$ maka dapat disimpulkan bahwa tidak ada masalah multikolinieritas (Ghozali, 2016).

\section{HASIL DAN PEMBAHASAN}

Penelitian ini melakukan pengumpulan data dengan menyebarkan kuesioner ke 34 LPD Se-Kota Denpasar. Kuesioner disebarkan kepada responden sebanyak 84 kuesioner dan seluruh kuesioner yang disebarkan kembali dan terisi lengkap, sehingga seluruh kuesioner dapat digunakan untuk pengujian hipotesis. Jika dilihat dari karakteristik responden yang mengisi kuesioner sebagian besar responden adalah perempuan yaitu sebanyak 40 orang perempuan dan 44 orang laki-laki. Sebaran responden terbanyak berdasarkan lama bekerja yaitu > 10 tahun sebanyak 56 orang, antara 6-10 tahun sebanyak 14 orang, antara 1-5 tahun sebanyak 14 orang. Berdasarkan tingkat pendidikan responden tertinggi memiliki jenjang pendidikan $\mathrm{S} 1$ yaitu 43 orang, pendidikan SMA sejumlah 31 orang, kemudian Diploma sejumlah 8 orang, sedangkan responden yang paling rendah 
berasal dari Pendidikan S2 yaitu sejumlah 2 orang.

Pengujian kualitas instrumen dari sisi validitas dan reliabilitas menunjukkan hasil seperti pada Tabel 1 .

Tabel 1.

Hasil Uji Kualitas Instrumen

\begin{tabular}{|c|c|c|c|c|}
\hline \multirow[b]{2}{*}{ Variabel } & \multirow[b]{2}{*}{ Item } & \multicolumn{2}{|c|}{ Validitas } & \multirow[b]{2}{*}{$\begin{array}{l}\text { Reliabi } \\
\text { litas }\end{array}$} \\
\hline & & $\begin{array}{c}\text { Korela } \\
- \text {-si }\end{array}$ & $\begin{array}{l}\text { Probabi- } \\
\text { litas }\end{array}$ & \\
\hline $\begin{array}{l}\text { Pencegahan } \\
\text { Kecurangan } \\
\text { (Y) }\end{array}$ & $\begin{array}{l}\mathrm{Y}_{1.1^{-}} \\
\mathrm{Y}_{1.25}\end{array}$ & $\begin{array}{l}0,651- \\
0.805\end{array}$ & 0,000 & 0,963 \\
\hline $\begin{array}{l}\text { Whistleblow } \\
\text { ing (X1) }\end{array}$ & $\begin{array}{l}\mathrm{X}_{1.1^{-}} \\
\mathrm{X}_{1.8}\end{array}$ & $\begin{array}{l}0,761- \\
0,833\end{array}$ & 0,000 & 0,925 \\
\hline $\begin{array}{l}\text { Hukum } \\
\text { Karma } \\
\text { Phala (X2) }\end{array}$ & $\begin{array}{l}\mathrm{X}_{2.1^{-}} \\
\mathrm{X}_{2.7}\end{array}$ & $\begin{array}{l}0,792- \\
0,850\end{array}$ & 0,000 & 0,924 \\
\hline $\begin{array}{l}\text { Moralitas } \\
\text { (X3) }\end{array}$ & $\begin{array}{l}X 3.1^{-} \\
X_{3.6}\end{array}$ & $\begin{array}{l}0,718- \\
0,874\end{array}$ & 0,000 & 0,876 \\
\hline
\end{tabular}

Sumber: Data Penelitian 2021

Pengujian asumsi klasik dilakukan untuk menilai kelayakan model regresi. Uji asumsi klasik yang dilakukan terdiri dari uji normalitas, uji multikolinearitas, dan uji heteroskedastisitas. Hasil pengujian dapat dilihat pada Tabel 2.

Tabel 2.

Hasil Pengujian Asumsi Klasik

\begin{tabular}{|c|c|c|c|}
\hline \multirow{2}{*}{ Variabel } & \multicolumn{2}{|c|}{ Multikolinearitas } & \multirow{2}{*}{$\begin{array}{l}\text { Heteroske- } \\
\text { dastisitas }\end{array}$} \\
\hline & VIF & Tolerance & \\
\hline $\begin{array}{l}\text { Whistleblowing } \\
\text { (X1) }\end{array}$ & 1.403 & 0.713 & 0.000 \\
\hline $\begin{array}{l}\text { Hukum Karma } \\
\text { Phala (X2) }\end{array}$ & 3.324 & 0.301 & 0.548 \\
\hline Moralitas (X3) & 3.292 & 0.304 & 0.836 \\
\hline $\mathrm{X} 1 * \mathrm{X} 2$ & 3.335 & 0.300 & 0.856 \\
\hline $\mathrm{X} 1 * \mathrm{X} 3$ & 3.573 & 0.280 & 0.231 \\
\hline
\end{tabular}

Sumber: Data Penelitian 2021
Hasil uji normalitas menunjukkan nilai signifikansi 0,185 di atas 0,05 sehingga dapat disimpulkan bahwa persamaan regresi terdistribusi secara normal. Pengujian multikolinearitas awal menunjukkan nilai VIF $>10$ dan tolerance $<0,1$ sehingga persamaan regresi mengandung multikolinearitas. Selanjutnya dilakukan transformasi data menggunakan metode first difference sehingga menghasilkan nilai VIF dan tolerance seperti pada Tabel 2. Setelah dilakukan transformasi maka persamaan regresi sudah bebas dari masalah multikolinearitas. Uji heteroskedastisitas menunjukkan nilai signifikansi seluruh variabel bebas berada di atas 0,05 sehingga persamaan regresi tidak mengalami masalah heteroskedastisitas.

Tabel 3.

Hasil Uji Hipotesis

\begin{tabular}{lllll}
\hline $\begin{array}{l}\text { Variabel } \\
\mathrm{X}\end{array}$ & $\begin{array}{l}\text { Koefisien } \\
\text { Regresi }\end{array}$ & $\begin{array}{l}\text { Standard } \\
\text { Error }\end{array}$ & $\begin{array}{l}\mathrm{t} \\
\text { hitung }\end{array}$ & \\
\hline $\mathrm{X} 1$ & 0.775 & 0.224 & 3.456 & 0.001 \\
$(\mathrm{X} 2)$ & -0.309 & 0.342 & -0.904 & 0.369 \\
$(\mathrm{X} 3)$ & 0.847 & 0.451 & 1.877 & 0.064 \\
$\mathrm{X} 1 * \mathrm{X} 2$ & 0.191 & 0.089 & 2.149 & 0.035 \\
$\mathrm{X} 1 * \mathrm{X} 3$ & 0.222 & 0.105 & 2.109 & 0.038 \\
& & & & \\
Constant & $-0,851$ & $\mathrm{~F}$ hitung & 24.404 & \\
Adjusted & 0,588 & Sig. & 0,000 & \\
R square & & & & \\
\hline
\end{tabular}

Sumber: Data Penelitian 2021

Hasil uji moderated regression analysis pada Tabel 3 menunjukkan bahwa persamaan regresi layak untuk dilanjutkan dengan nilai F-hitung 24,404 dan signifikasi 0,000. Variabel penelitian yaitu whistleblowing berpengaruh positif pada pencegahan kecurangan di LPD Kota Buletin Studi Ekonomi 
Denpasar dengan signifikansi 0,001 di bawah 0,05 . Hasil pengujian variabel moderasi menunjukkan bahwa keyakinan hukum karma phala dan moralitas memoderasi hubungan whistleblowing dan pencegahan kecurangan dengan nilai signifikansi 0,035 dan 0,038 di bawah 0,005. Nilai adjusted $R$-square sebesar 0,588 menunjukkan bahwa 58,8 persen pencegahan kecurangan dipengaruh oleh variabel whistleblowing, penerapan hukum karma phala, dan moralitas, sisanya 41,2 persen dijelaskan oleh variabel lain yang tidak dimasukkan dalam model penelitian.

Hasil penelitian menunjukkan bahwa whistleblowing berpengaruh positif pada pencegahan kecurangan. (Komite Nasional Kebijakan Governance (KNKG), 2011) berpandangan bahwa efektivitas whistleblowing akan meningkatkan peran serta masyarakat dan karyawan perusahaan agar berani bertindak dalam rangka pencegahan fraud dan korupsi dengan melakukan pelaporan pada pihak yang berwenang. Pemahaman mengenai mekanisme whistleblowing dan perlindungan pelapor akan membuat karyawan termotivasi untuk melaporkan kecurangan apapun kepada otoritas yang berwenang (Pamungkas et al., 2017). Romadaniati et al., (2020); Pamungkas et al., (2017) menemukan bahwa whistleblowing berpengaruh positif pada pencegahan kecurangan. Penelitian Jayanti \& Suardana, (2019) juga menemukan bahwa whistleblowing berpengaruh positif pada pencegahan kecurangan. Patel (2003); Miceli et al., (2013) menemukan bahwa para regulator dan akuntan di Amerika Serikat dan beberapa negara lain telah mengakui efektifitas whistleblowing untuk mengungkapkan kecurangan yang terjadi pada laporan keuangan. Adanya globalisasi dalam perdagangan oleh perusahaan yang terdaftar di bursa nasional memberi motivasi pada badan legislatif di berbagai negara untuk merancang peraturan guna meningkatkan perlindungan ketika melakukan penerapan whistleblowing (Lewis, 2008; Miceli et al., 2013; Schmidt, 2005).

Hasil penelitian juga menunjukkan bahwa penerapan hukum karma phala berpengaruh positif pada hubungan whistleblowing dan pencegahan kecurangan. Konsep karma memiliki selalu diterapkan sebagai filosofi tindakan praktis. Menurut filosofi ini, karma bukan hanya hukum spiritual, tetapi juga prinsip yang menuntut niat baik. Individu yang percaya pada hukum karma akan bertindak mengelola pikiran dan emosi dengan baik untuk dapat mengambil keputusan yang etis (Fraedrich \& Ferrell, 1992; Aksiana \& Sujana, 2019). Seseorang diharapkan akan memperbaiki etika dan moral dalam hidup bermasyarakat jika memiliki keyakinan pada hukum karma phala (Munidewi, 2017). Vinayanthi et al., (2020) menemukan bahwa kayakinan hukum karma phala memperkuat hubungan idealisme dan komitmen profesional pada perilaku etis. Dapat disimpulkan bahwa seseorang yang memiliki keyakinan pada hukum karma phala akan berperilaku etis sehingga ketika melihat terjadinya kecurangan mereka akan menggunakan mekanisme pelaporan yang ada (wisthleblowing system) untuk mencegah terjadinya kecurangan tersebut.

Beberapa penelitian juga menemukan adanya pengaruh positif moralitas pada hubungan wisthleblowing dan pencegahan 
kecurangan. Seorang individu yang memiliki level intensitas moral yang lebih tinggi cenderung akan berlaku adil dan melakukan tindakan yang benar (Kreshastuti \& Prastiwi, 2014). Penelitian Manafe, (2015) juga berpandangan bahwa tingkat penalaran moral mempengaruhi kecenderungan seseorang untuk melakukan whistleblowing. Seseorang yang memiliki tingkat moralitas yang lebih tinggi akan cenderung melakukan whistleblowing jika dibandingkan dengan individu yang memiliki tingkat level moralitas rendah. Fraud yang terjadi dapat dideteksi atau juga dapat dicegah dengan adanya perilaku etis yang dimiliki oleh pegawai yang mempengaruhi persepsi mereka terhadap whistleblowing system (Pamungkas et al., 2017). Oleh karena itu, individu yang memiliki intensitas moral tinggi akan cenderung melakukan pelaporan jika terjadi tindakan melanggar hukum (whistleblowing) karena merasa bahwa perbuatan tersebut tidak benar demi meberikan kebaikan bagi orang lain (Urumsah et al., 2018).

\section{SIMPULAN DAN SARAN}

Berdasarkan hasil pengujian hipotesis dan pembahasan dapat disimpulkan bahwa wisthleblowing berpengaruh positif pada pencegahan kecurangan. Penerapan wisthleblowing nilai efektif dalam upaya pencegahan kecurangan dalam sebuah organisasi. Keyakinan hukum karma phala mampu memoderasi hubungan wisthleblowing dan pencegahan kecurangan. Individu yang memiliki keyakinan hukum karma phala akan memanfaatkan sistem wisthleblowing untuk membantu organisasi dalam mencegah terjadinya kecurangan. Moralitas individu juga mampu memoderasi hubungan wisthleblowing dan pencegahan kecurangan. Sistem wisthleblowing akan lebih efektif dalam pencegahan kecurangan ketika individu dalam organisasi memiliki tingkat moralitas yang tinggi.

Hasil penelitian memberikan gambaran bahwa wisthleblowing adalah salah satu mekanisme yang dapat diterapkan oleh organisasi untuk membantu mencegah terjadinya kecurangan. LPD sebagai lembaga keuangan masyarakat Bali diharapkan dapat menerapkan sistem ini untuk membantu mencegah terjadinya kecurangan. Organisasi perlu juga mempertimbangkan tingkat moralitas dan keyakinan hukum karma pada anggota organisasi agar penerapan wisthleblowing menjadi lebih efektif. Lembaga yang menaungi LPD dapat mempertimbangkan untuk menerbitkan aturan mengenai penerapan wisthleblowing system dalam upaya pencegahan kecurangan.

\section{REFERENSI}

Aksiana, I. B. W., \& Sujana, I. K. (2019). Effect of Risk Preference, Professional Domination, Information, and Professional Relationship on Ethical Decision Making of Tax Consultants. International Research Journal of Management, IT and Social Sciences, 6(4), 174-179. https://doi.org/10.21744/irjmis.v6n4.675

Brownell, P. (1983). Leadership style, budgetary participation and managerial behavior. Accounting, Organizations and Society, 8(4), 307-321. https://doi.org/10.1016/03613682(83)90046-6

Cahyo, M. N., \& Sulhani. (2017). Analisis Empiris Pengaruh Karakteristik Komite Audit, Karakteristik Internal Audit, Whistleblowing System, Pengungkapan Kecurangan Terhadap 
Moderasi Keyakinan Hukum Karma dan Moralitas... Yuniasih, Dkk

Reaksi Pasar. Dinamika Akuntansi Dan Bisnis, 4(2), 249-270-321.

Chakraborty, D., \& Chakraborty, S. K. (2006). The "Nishkam Karma" Principle: Its Relevance to Effectiveness and Ethics. IIMB Management Review (Indian Institute of Management Bangalore), 18(2), 115-125.

Dyck, A., Morse, A., \& Zingales, L. (2010). Who blows the whistle on corporate fraud? Journal of Finance, 65(6), 2213-2253. https://doi.org/10.1111/j.15406261.2010.01614.x

Fraedrich, J. P., \& Ferrell, O. C. (1992). The impact of perceived risk and moral philosophy type on ethical decision making in business organizations. Journal of Business Research, 24(4), 283-295. https://doi.org/10.1016/01482963(92)90035-A

Gaurina, N. P. M., Purnamawati, I. G. A., \& Atmadja, A. T. (2017). Pengaruh Persepsi Karyawan Mengenai Perilaku Etis dan Whistleblowing System Terhadap Pencegahan Fraud (Studi Kasus pada Bali Hai Cruises). JIMAT (Jurnal Ilmiah Mahasiswa Akuntansi) Universitas Pendidikan Ganesha, 8(2), 1-10.

Ghozali, I. (2016). Aplikasi Analisis Multivariate dengan Program IBM SPSS 23. (Edisi 8). Semarang: Badan Penerbit Universitas Diponegoro.

Hafizhah, I. (2016). Pengaruh Etika Uang (Money Ethics) Terhadap Kecurangan Pajak (Tax Evasion) Dengan Religiusitas,Gender dan Materialisme Sebagai Variabel Moderasi. Jurnal Online Mahasiswa (JOM) Bidang Ilmu Ekonomi, 3(1), 1652-1665.

Hakim, T., Subroto, B., \& Andayani, W. (2017). Faktor Situasional dan Demografis sebagai Prediktor Niat Individu untuk Melakukan Whistleblowing. Jurnal Ilmiah Administrasi Publik, 3(2), 134-142. https://doi.org/10.21776/ub.jiap.2017.003.02. 6

Hariawan, I. M. H., Sumadi, N. K., \& Erlinawati, N. W. A. (2020). Pengaruh Kompetensi Sumber Daya Manusia, Whistleblowing System, dan Moralitas Individu terhadap Pencegahan Kecurangan (Fraud) dalam Pengelolaan Keuangan Desa. Hita Akuntansi Dan Keuangan, 1(1), 586-618.

Transparency International. (2020). Corruption Perception Index 2018. Retrieved from: https://ti.or.id/corruption-perception-index2018/
Jayanti, L. S. I. D., \& Suardana, K. A. (2019). Pengaruh Kompetensi SDM, Moralitas, Whistleblowing dan SPI Terhadap Pencegahan Fraud Dalam Pengelolaan Keuangan Desa. E-Jurnal Akuntansi, 29(3), 1117-1131. https://doi.org/10.24843/eja.2019. v29.i03.p16

Kreshastuti, D. K., \& Prastiwi, A. (2014). Analisis Faktor-Faktor Yang Mempengaruhi Whistleblowing (Studi Empiris pada Kantor Akuntan Publik di Semarang). Diponegoro Journal of Accounting, 3(2), 389-403

Lewis, D. (2008). Ten years of public interest disclosure legislation in the UK: Are whistleblowers adequately protected? Journal of Business Ethics. https://doi.org/10.1007/s10551-008-9899-5

Manafe, M. W. . (2015). Pengaruh Penalaran Moral, Retaliasi Dan Gender Terhadap Kecenderungan Whistleblowing Internal. Wahana, 18(2), 113-125.

Miceli, M. P., Near, J. P., \& Dworkin, T. M. (2013). Whistle-blowing in organizations. New York: Psychology Press

Munidewi, I. A. B. (2017). Akuntabilitas dalam Perspektif Ajaran Karma Phala Sebagai Pedoman Untuk Membangun Karakter Auditor. Jurnal Ilmiah Akuntansi Dan Bisnis, 12(1), 54-64. https://doi.org/10.24843/jiab. 2017.v12.i01.p07

Pamungkas, I. D., Ghozali, I., \& Achmad, T. (2017). The effects of the whistleblowing system on financial statements fraud: Ethical behavior as the mediators. International Journal of Civil Engineering and Technology, 8(10), 15921598.

Parmawan, I. G. P., Sujana, E., \& Purnamawati, I. G. A. (2017). Pengaruh Internal Control, Budaya Etis Organisasi, Kesesuaian Kompensasi dan Proteksi Awig-Awig Terhadap Kecenderungan Kecurangan (Fraud). E-Jurnal S1 Ak Universitas Pendidikan Ganesha, 8(2), $1-13$.

Patel, C. (2003). Some Cross-Cultural Evidence on Whistle-Blowing as an Internal Control Mechanism. Journal of International Accounting Research, 2(1), 69-96. https://doi.org/10.2308/jiar.2003.2.1.69

Purnamawati, I. G. A. (2018). Individual Perception of Ethical Behavior and Whistleblowing on Fraud Detection through Self-Efficacy. Jurnal Keuangan Dan Perbankan, 22(2), 362-372. https://doi.org/10.26905/jkdp.v22i2.1991 
Moderasi Keyakinan Hukum Karma dan Moralitas... Yuniasih, Dkk

Purnamawati, I. G. A., \& Adnyani, N. K. K. S. (2019). Peran Komitmen, Kompetensi, Dan Spiritualitas Dalam Pengelolaan Dana Desa. Jurnal Akuntansi Multiparadigma, 10(2), 227240.https://doi.org/10.18202/jamal.2019.08.10 013

Rahimah, L. N., Murni, Y., \& Lysandra, S. (2018). Pengendalian Dan Moralitas Individu Terhadap Pencegahan Fraud Yang Terjadi Dalam Pengelolaan Alokasi Dana Desa (Studi Kasus Di Desa Sukamantri, Desa Sukamanah, Desa Sukaresmi Dan Desa Gunungjaya Kecamatan Cisaat Kabupaten Sukabumi). Jurnal Ilmiah Ilmu Ekonomi, 6(12), 139-154

Romadaniati, Taufik, T., \& Nazir, A. (2020). Pengaruh kompetensi aparatur desa, sistem pengendalian internal, dan whistleblowing system terhadap pencegahan fraud pada pemerintah desa dengan moralitas individu sebagai variabel moderasi. (studi pada desadesa di kabupaten bengkalis). Bilancia: Jurnal Ilmiah Akuntansi, 4(3), 227-237

Rustiarini, N. W., \& Sunarsih, N. M. (2017). Factors influencing the whistleblowing behaviour: A perspective from the theory of planned behaviour. Asian Journal of Business and Accounting, 10(2), 187-214

Schmidt, M. (2005). "Whistle blowing" regulation and accounting standards enforcement in Germany and Europe - An economic perspective. International Review of Law and Economics, 25(2), 143-168. https://doi.org/10.1016/ j.irle.2005.06.001

Sugiyono. (2017). Metode Penelitian Kuantitatif, Kualitatif, dan $R \& D$. Bandung: Alfabeta,

Sujana, I. K., Suardikha, I. M. S., \& Laksmi, P. S. P. (2020). Whistleblowing System, Competence, Morality, and Internal Control System Against Fraud Prevention on Village Financial Management in Denpasar. E-Jurnal Akuntansi, $\quad 30(11), \quad 2780-2794$. https://doi.org/10.24843/eja.2020.v30.i11.p06

Urumsah, D., Wicaksono, A. P., \& Hardinto, W. (2018). Pentingkah Nilai Religiusitas dan Budaya Organisasi untuk Mengurangi Kecurangan? Jurnal Akuntansi Multiparadigma, $9(1), \quad 156-172$. https://doi.org/10.18202/jamal.2018.04.9010

Vinayanthi, N. M., Wirakusuma, M. G., Suprasto, H. B., \& Putri, I. G. A. M. A. D. (2020). belief on the law of karma moderates the effect of idealism and professional commitment on the ethical decisions of tax consultants.
International Research Journal of Management, IT and Social Sciences, 7(6), 175-183. https://doi.org/10.21744/irjmis.v7n6. 1035

Wijaya, K. D. S., Sujana, E., \& Purnamawati, I. G. A. (2017). Pengaruh Efektivitas Pengendalian Internal, Kesesuaian Kompensasi, Moralitas Individu, Dan Whistleblowing Terhadap Kecenderungan Kecurangan Akuntansi Pada Lpd Di Kecamatan Gerokgak. E-Journal S1 Ak Universitas Pendidikan Ganesha, 7(1), 112.

Ziegenfuss, D. E., \& Singhapakdi, A. (1994). Professional Values and the Ethical Perceptions of Internal Auditors. Managerial Auditing Journal, 9(1), 34-44. https://doi.org/10.1108/02686909410050433 